\title{
Combustion Performance of Biomass Composite Briquette from Rice Husk and Banana Residue
}

\author{
Munira Mohamed Nazari" ${ }^{\# *}$, Chin Pooi San ", Nor Amira Atan ${ }^{\#}$ \\ ${ }^{\#}$ School of Bioprocess Engineering, Universiti Malaysia Perlis, 02600 Arau, Perlis, Malaysia \\ E-mail: "muniranazari@unimap.edu.my
}

\begin{abstract}
Utilization of agro-waste material in producing biomass briquette has been actively explored due to its huge potential as an alternative option to current energy resources. Also, the development of biomass briquette also solved agricultural waste disposal issues. Biomass briquette is widely utilized for domestic and industrial purposes such as cooking, heating, and electricity generation. This study was conducted to assess the combustion performance of the biomass composite briquette, which was produced by combining two agro-waste materials, which are rice husk and banana residue. The composite briquette was densified at a constant and controlled temperature as well as pressure by varying the particle size and ratio of the raw materials. The particle size used were $300 \mu \mathrm{m}, 150 \mu \mathrm{m}$ and $75 \mu \mathrm{m}$ and then these particles were blended in the various components of rice husk and banana residue in percentage composition of 100:0, 80:20 and 60:40, respectively. The combustion performances of composite briquette ware assessed by evaluating their burning rate, calorific value, volatile matter, ash content and fixed carbon content. Results showed the composition of rice husk and banana residue of $60: 40$ with the particle size of $150 \mu \mathrm{m}$ were found as the optimal combination since it owned moderate density, ash and fixed carbon content, and volatile matter. Furthermore, the combustion performance results of these briquette mixtures generate the calorific value up to $16396 \mathrm{~J} / \mathrm{g}$ and could retain for at least 14 minutes after the flame was gradually put out by itself that indicated it has potential to be applied as solid fuel.
\end{abstract}

Keywords - composite briquette; combustion performance; composition.

\section{INTRODUCTION}

Biomass briquette developed from agricultural waste can consider as a potential source for renewable energy due to the sustainability of resource, positive impact on environment and cost-effectiveness. At the same time, there was encouraged by the Malaysian government to grow green for sustainability, reduce dependency on conventional energy and to explore new renewable energy sources [1]-[3]. Through this opportunity, many researchers had developed new formulation on turning the waste product into briquette. Briquette is widely used by the household and industrial sectors for heating and generation of power [4]. Briquette also knew, as fire starter will undergo densification process involving compaction of loose combustible material and reduction of moisture content in a uniform shape [5].

Based on previous research, most researchers are aimed not only to study the potential of agricultural waste as briquette but also to study the best mixture ratio and to produce a great performance of briquette in terms of its physical, chemical and combustion properties. Such example, A. Rahman et al. [2014] converting palm oil empty fruit bunch (EFB) into briquette through pyrolysis process where char and pyrolysis liquid were mixed at various percentages concentration of $90: 10,80: 20,70: 30$ and 60:40 [6]. The proportion of the mixture influences the physical and combustion properties of the briquettes. The results showed that 70:30 mixture has optimal properties to work as a briquette. However, there are still a lot of opportunities in exploring the quality of the formulations, particularly combustion performance.

The quality of the briquettes also was affected by moisture content, temperature, and size of particles. Ideal briquettes are described to have feasible sizes used during transportation purposes, higher density, energy content, and long-lasting burning duration [7]. Besides, densification of raw materials containing lignin will help to improve the binding ability of particles inside the briquette. The higher content of lignin yield better briquette strength [8].

In this study, rice husk and banana residue were used as a briquetting material as both materials currently abundantly in Malaysia and are a good source of lignin. Rice husk is generated during rice production and accounts for $20 \%$ of the total weight of rice product and normally will be either burnt or dumped as waste [9]. The content of rice husk is composed of cellulose (35\%), hemicellulose $(25 \%)$, lignin $(20 \%)$, crude protein $(3 \%)$, and ash (17\%) [10]. On the other hand, banana residues are also a good source of lignin (6- 
12\%) [11]. The banana was the second largest cultivated in Malaysia and generates major volume of wastes at almost $200 \mathrm{t} / \mathrm{ha} /$ year and usually dispose of in the landfill without proper disposal [12]-[13].

The main objective of this paper was to assess the optimum combustion performance of biomass composite briquette produced from rice husk and banana residue. Physical and combustion analysis was carried out to investigate the effect of raw materials particle size and mixing ratio on combustion performance.

\section{MATERIAL AND METHOD}

\section{A. Acquisition and Preparation of Raw Materials}

The biomass composite briquette comprises of rice husk and banana residue. Both waste materials were collected from local rice mills and fried banana stalls in Perlis, Malaysia. Both waste materials were then dried under direct sunlight for about three to four days to reduce the moisture content until $8 \%$. The moisture content of the sample was determined by using Ohaus ${ }^{\mathrm{TM}}$ MB25 Moisture Analyzer.

\section{B. Production of Biomass Composite Briquette}

The dried samples of rice husk and banana residue were ground separately using a grinder to reduce the size of the particles. Each sample was then separated by using a sieving machine into three particle sizes of $300 \mu \mathrm{m}, 150 \mu \mathrm{m}$, and 75 $\mu \mathrm{m}$ respectively and tightly stored in a polyethylene bag.

The briquetting process involves a densification process using a hot press machine with a cylindrical mold dimension of $3.0 \mathrm{~cm} \times 3.0 \mathrm{~cm}$. Densification is the mechanical process of compacting the biomass residue into solid fuel. It has higher density and energy content as well as less moisture compared to its raw materials. These processes are between ways to improve the behavior of fuel because it increases the homogeneity and facilitates the logistic and storage of fuel [14]. In this study, the composite briquettes were prepared without addition of chemical binder and the materials were combined at mixing proportion of 100:0, 80:20, and 60:40 respectively (Rice husk: Banana residue). The composite briquette was pressurized with a temperature of $180{ }^{\circ} \mathrm{C}$ for about 30 minutes. Fig. 1 shows the example of composite biomass briquette produced from rice husk and banana residue.

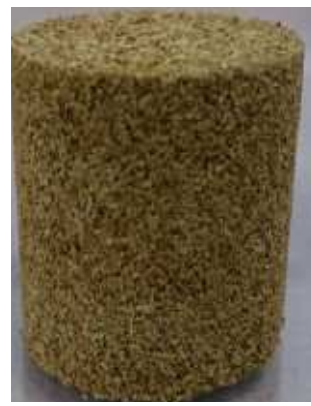

Fig. 1 Biomass composite briquette produced

\section{Physical and Combustion Testing}

The quality of the briquette was measured by its physical properties and combustion performance. In this study, there were seven physical and combustion tests, which examine density, ignition time, burning rate, calorific value, ash content, volatile matter and fixed carbon content of the briquette. For each experiment, three replications for each composition were done.

1) Density: The density for each composite briquette composition was determined after the ejection from the mold and was calculated from the ratio of the mass to the volume of briquette. The mass of the composite briquette was obtained by using analytical balance, while the volume was calculated by taking the linear dimensions (length, width, and height) of the briquette. The density was calculated as follows:

$$
D_{b}=\frac{M_{b}}{V_{b}}
$$

where $D_{b}$ is the density of the briquette, $M_{b}$ is the mass of the briquette in and $V_{b}$ is the volume of the briquette.

2) Ignition Time: Ignition time was the time required for the briquette to ignite. Composite briquette was ignited at a free corner and the time required for burning to be initiated recorded to determine the ignition time. Once the spark had been ignited, the duration of the burning of the briquette was recorded.

3) Burning rate: Burning rate defined as the ratio of the distance burnt to the total time taken. In this study, composite briquette was placed on wire gauze before ignition of the burner. The time taken was measured from the beginning of the ignition until the fire extinguisher. The burning rate was then determined as follows:

$$
\text { Burning rate }=\frac{\text { Length burnt }(\mathrm{cm})}{\text { Time taken }(\mathrm{s})}
$$

4) Calorific value testing: This test determines the total heat release by the briquette when complete combustion occurs. Automated Bomb Calorimeter C 2000 Basic as shown in Fig. 2 is used in determining the calorific value of the produced briquette. It is automatically measured and calculated as follows:

$$
C v(J / g)=\frac{\text { Measured value }(J)-\text { Complete combustion }(J)}{\text { Sample size }(g)}
$$

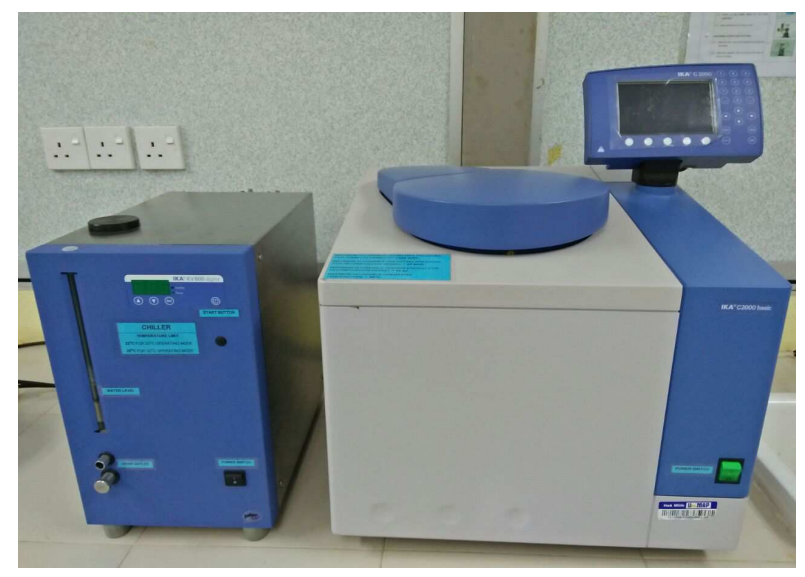

Fig. 2 Bomb Calorimeter C 2000 Basic 
5) Ash Content: The ash content (AC) of the composite briquette was carried out by using ASTM E1755-01 (2007) where the burning process of the briquette took placed inside the furnace at $575{ }^{\circ} \mathrm{C}$ for 4 hours and then transferred to desiccators for cooling down [15]. Ash content was calculated as the equation:

$$
\% \text { AshContent }=\left(\frac{M_{\text {ash }}}{M_{\text {briquette }}}\right) x 100
$$

where $M$ is the mass of the sample.

Ash content produced by the composite briquette will influence the calorific value test. The ash content is inversely proportional to its calorific value [16]. At the same time, ash content is an important characteristic of briquette for ash handling and disposal requirement.

6) Volatile Matter: Volatile matter (VM) involves vaporization of the material. In the furnace, $2 \mathrm{~g}$ of composite briquette sample was heated in a partially closed crucible to about $550{ }^{\circ} \mathrm{C}$ for 10 minutes inside the furnace. Then, the crucible and its content were cooled in desiccators. The volatile matter was determined as follows:

$$
\% \text { Volatile Matter }=\left(\frac{W_{i}-W_{f}}{W_{i}}\right) \times 100
$$

where $W_{i}$ and $W_{f}$ are the initial weight of the sample before and after burned, respectively in the furnace.

7) Fixed Carbon Content: Fixed carbon content was the carbon available for the combustion process, but it was not the total amount of carbon within the briquettes produced. This is because a significant amount of carbon would be released as hydrocarbons in the volatiles [17]. In this study, analysis of fixed carbon was determined through the solid combustible residue that remains after a coal particle was heated and the volatile matter was expelled. The following equation was being used:

$$
\% \text { Fixed Carbon }=100 \%-(\% V M+\% A C)
$$

where $V M$ and $A C$ are the volatile matter and ash content of the sample [18].

\section{RESULTS AND DISCUSSIONS}

\section{A. Physical Properties}

In this study, the evaluation of physical properties was measured through the density of the composite briquette. Based on results obtained, density produced was affected by particle size and mixing ratio of raw material. Fig. 3 illustrates the effect of particle size on density with different mixing ratio. Figure 3 indicates that the density of the composite briquette increases as the particle size decreases. This is because the particle with smaller sizes can fill in the voids spaces and thus enhance the compaction of the briquette. Therefore, reduction of particle size provides larger contact surface area in and thus lowers the porosity of the composite briquette.

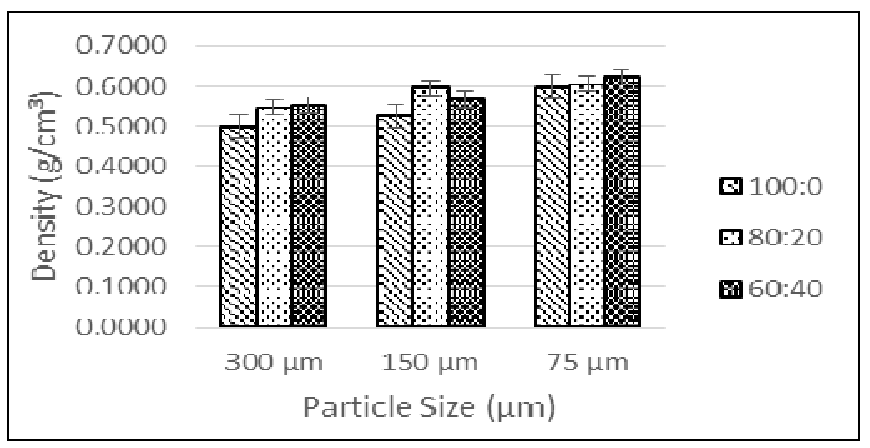

Fig. 3 Effect of particle size with different mixing ratio on density

Furthermore, the density of briquette increases with an increasing amount of banana residue. Composite briquette of $75-\mu \mathrm{m}$ particle size with a mixing ratio of $60: 40$ had the highest density value, which was $0.62 \mathrm{~g} / \mathrm{cm}^{3}$ and followed by $150 \mu \mathrm{m}$ and $300 \mu \mathrm{m}$, respectively. This indicates the bonding of adjacent particles improves with increasing banana residue amount. This is possible because banana residue contains $3 \%$ of starch content that acts as a binder. Briquette is bonding better with the addition of banana residue and maintaining their compacting form after densification process [19].

\section{B. Combustion Properties}

Results on ignition time, burning rate and calorific value test were analyzed to examine the combustion properties of the composite biomass briquette from rice husk and banana residue. At the same time, the effect of the particle size and mixing ratio were also examined. Fig. 4 shows the ignition time required by each composite briquette prepared.

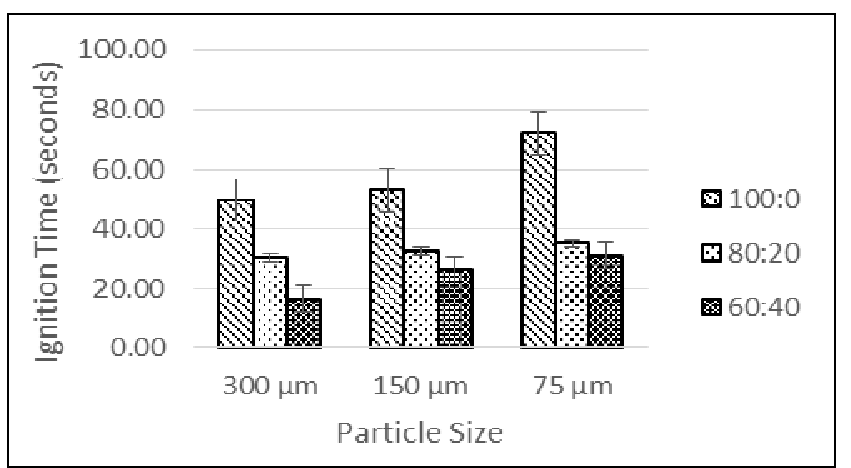

Fig. 4 Effect of particle size with the different mixing ratio of ignition time

According to the graph, it has clearly shown that the particle size and mixing ratio of materials influence the time taken to ignite. Ignition time of briquettes was prolonged with smaller particle size. The longer ignition time was recorded by $100 \%$ briquette from rice husk with $75-\mu \mathrm{m}$ particle size (72.22 seconds). Meanwhile, the minimal ignition time is taken which it was recorded by composite briquette of $300 \mu \mathrm{m}$ with 60:40 mixing ratio followed by 26.32 seconds and 31.07 seconds for $150 \mu \mathrm{m}$ and $75 \mu \mathrm{m}$, respectively. This is because combustion of the rice husk contains $87.97 \%$ silica in an amorphous form, which can prevent oxygen from reaching the carbon inside during 
combustion process [20]. However, ignition time was accelerate with the presence of banana residue in the briquette composition. But additional of $20 \%$ banana residue in the briquette composition didn't show so much influence as it might not achieve the optimal condition in speeding up the ignition time. The banana residue contains carbohydrate content, which is resistant starch and non-starch polysaccharides, which have low digestibility that may help in efficient combustion [21].

The burning rate was inversely proportional to the ignition time. When ignition time is longer, the burning rate is slower. The result is shown in Fig. 5 recorded smaller particle size had a longer burning rate. At particle size of 75 $\mu \mathrm{m}$ with mixing ratio of 100:0, 80:20, and 60:40, the average burning rate was $0.1476 \mathrm{~g} / \mathrm{min}, 0.2036 \mathrm{~g} / \mathrm{min}$, and 0.2055 $\mathrm{g} / \mathrm{min}$, respectively. The reason for this is attributed by fewer free spaces available for mass diffusion causing lower porosity in the briquette that reduce the combustion rate [19].

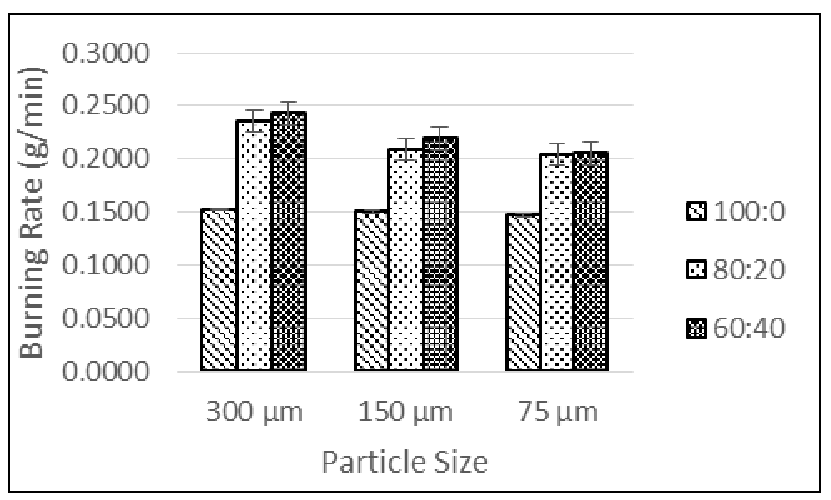

Fig. 5 Effect of particle size with different mixing ratio on burning rate

The results in Fig. Five also indicated that briquette composes from $100 \%$ rice husk burnt at the longer duration, but it has also shown that not so much effect by the size of the particle. The possible explanation could be due to its flame-retarding condition as rice husk has the special characteristic that is contained silica content up to $15-20 \%$ [10]. However, the presence of banana residue increases the burning rate of the composite briquette. They are consistent with the results shown in Fig. 4 where faster ignition time recorded with the presence of large banana residue amount in the briquette composition.

Meanwhile, results in Fig. 6 shown the calorific value obtained by each of the composite briquettes formulated. The graph in Fig. 6 recorded better calorific values for composite briquette produced were obtained with a larger particle size of $300 \mu \mathrm{m}$ followed by $150 \mu \mathrm{m}$ and $75 \mu \mathrm{m}$. The highest calorific value was $16396 \mathrm{~J} / \mathrm{g}$ by $300-\mu \mathrm{m}$ particle size with a ratio of 60:40 and the lowest was $15060 \mathrm{~J} / \mathrm{g}$ by $75-\mu \mathrm{m}$ particle size with ratio of 100:0. It was suggested larger particle sizes have a corresponding increase in thermal efficiency hence release more heat energy [18].

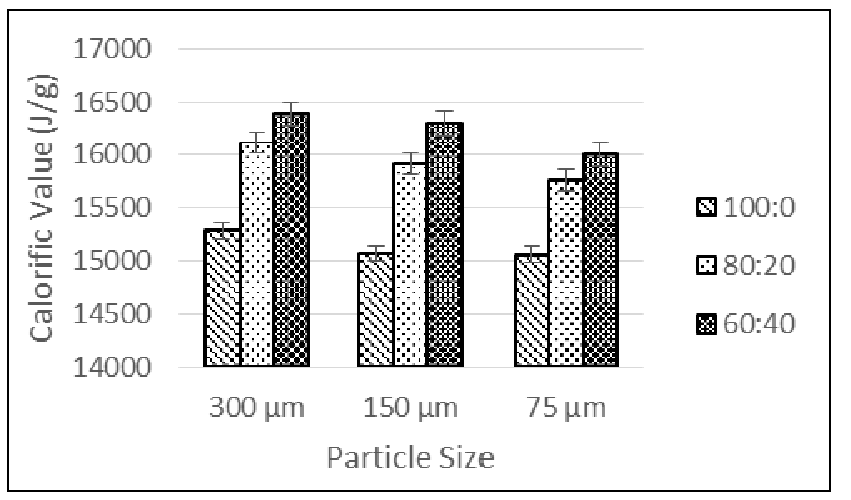

Fig. 6 Effect of particle size with different mixing ratio on calorific value

On top of that, calorific value increased with the amount of banana peel increased. This was due to the heating value of banana residue, and rice husk was $18.890 \mathrm{MJ} / \mathrm{kg}$ and $15.324 \mathrm{MJ} / \mathrm{kg}$, respectively. The outcome proposed that mixing raw materials of high calorific value with low calorific value would enhance the calorific value of the composite briquette. This situation also might influence by the degradation of $3 \%$ starch content in the banana residue that increases the calorific value [21].

These results were also compared to others published calorific values of biomass energy content done by other researchers such as groundnut shell briquette $(12600 \mathrm{~J} / \mathrm{g})$ [22], rice husk briquette (13389 J/g) [23], empty fruit bunch briquette $(17000 \mathrm{~J} / \mathrm{g}$ ) [24], coconut shell briquette $(29307 \mathrm{~J} / \mathrm{g})$ [25], and lastly cowpea briquette and soybeans briquette which had $14372 \mathrm{~J} / \mathrm{g}$ and $12953 \mathrm{~J} / \mathrm{g}$, respectively [26].

Overall, biomass composite briquette produced from rice husk and banana residue of mixing ratio 60:40 with particle sizes $300 \mu \mathrm{m}$ and $150 \mu \mathrm{m}$ released $16305 \mathrm{~J} / \mathrm{g}$ and $16396 \mathrm{~J} / \mathrm{g}$, respectively of calorific value. Hence, for application purpose, both formulated composite briquette is better and comparable with other biomass briquettes. Besides that, the energy values are sufficient to produce the heat required at least to work as a water boiler for household application and small-scale industrial thermal utilization that was $16096 \mathrm{~J} / \mathrm{g}$ [27].

\section{Effect of Particle Size and Mixing Ratio on Ash Content}

In this study, analysis of ash content was performed to find the effect of the particle size and material composition on ash content produced. Noted that higher ash content leads to higher dust emission and affect the combustion efficiency [24] and also the lower the ash content, the better the quality of the briquette. Fig. 7 shows the effect of particle size with different mixing ratio on the percentage of ash produced after the combustion process. 


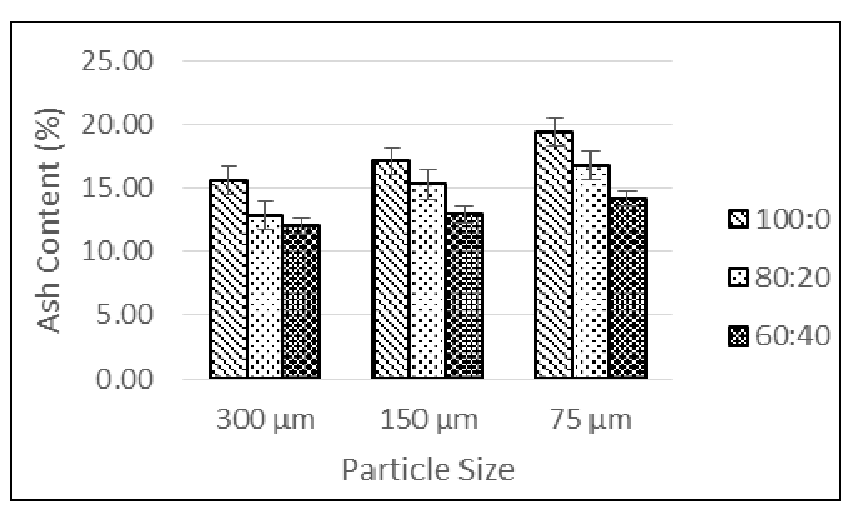

Fig. 7 Effect of particle size with different mixing ratio on ash content

Based on results, the lowest ash content was obtained by composite briquette of mixing ratio 60:40 which are $14.10 \%$, $12.91 \%$, and $11.99 \%$ for the particle size of $300 \mu \mathrm{m}, 150$ $\mu \mathrm{m}$, and $75 \mu \mathrm{m}$, respectively. Meanwhile, the highest ash content was obtained by composite briquette of $100 \%$ rice husk. It has shown that the addition of banana residue had lower down the composite briquette ash content but increase the calorific value. Result also shown larger particle size released less ash content compared to smaller particle size.

\section{Effect of Particle Size and Mixing Ratio on Volatile Matter}

The result of the volatile matter of the composite briquettes is presented in Fig.8. Volatile matter refers to the part of biomass that is released when the biomass is heated up to $500^{\circ} \mathrm{C}$. During the combustion process, composite briquette decomposed into volatile gasses and solid char. Note that higher volatile matter can ignite more easily and had higher reactive fuel that gave a faster combustion rate during the devolution phase [28]. Based on the results obtained as shown in Fig.8, the percentage of the volatile matter was directly proportional to the particle size. Larger particle size released more volatile matter compared to smaller particle size.

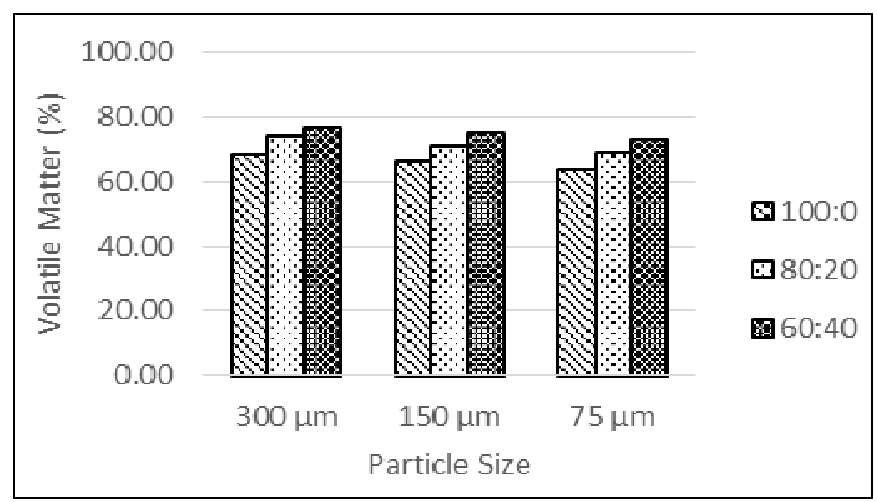

Fig. 8 Effect of particle size with different mixing ratio on volatile matter

The higher volatile matter released was obtained by composite briquette of $300 \mu \mathrm{m}$ with a mixing ratio of $60: 40$, which is $76.87 \%$. This is high and high volatile matter content indicates during the combustion process, composite briquette will volatilize and burn as gas in combustion chambers. This also indicates that more significant porosity of composite briquette enables the vapor or gas to leave more readily. Result also shown an increased amount of banana residue in the briquette composition released matter that is more volatile during the burning process.

\section{E. Fixed Carbon Content}

Results shown in Fig. 9 showed the particle size of the raw materials was a less significant effect on the fixed carbon content. This may be due to the solid uniform nature of the briquette that results in a slower heating rate during the combustion process. However, all these briquettes had low fixed carbon content (17\%) which is comparable with the findings of Nyakuma et al. [29].

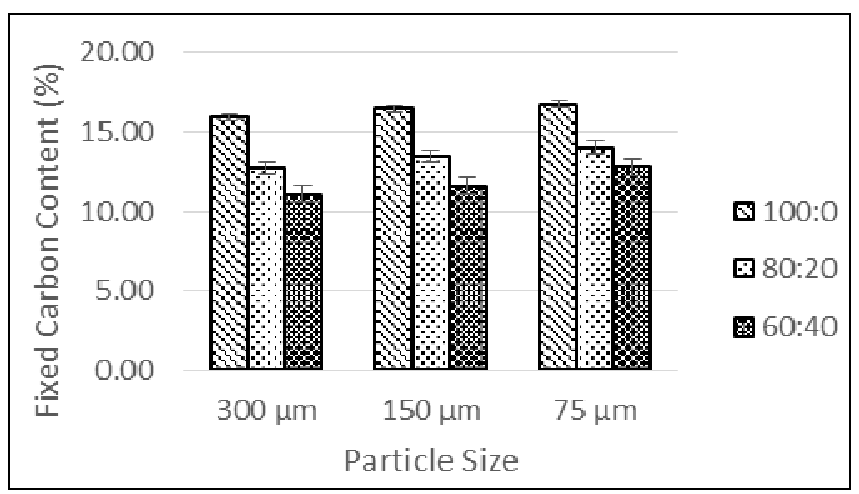

Fig. 9 Effect of particle size with different mixing ratio on the fixed carbon content

Low fixed carbon content makes it tend to prolong heating time by its low heat release. Also, fixed carbon content was dropped progressively due to the increased amount of banana residue. There had $16.79 \%$ followed by $14.07 \%$ and lastly $12.84 \%$ for a mixing ratio of $100: 0,80: 20$, and 60:40 respectively in particle size of $75 \mu \mathrm{m}$. This presented that the presence of banana residue enhances better binding between adjacent particles compared to briquette compose from $100 \%$ rice husk. $100 \%$ rice husk briquette had an unstable condition and easy to rupture during the burning process.

\section{CONCLUSIONS}

Based on the combustion performances, the biomass composite briquette produced from rice husk and banana residue exhibit excellent potential as a solid fuel and as an alternative on the current energy resources at least to work as water boiler for household application and small-scale industrial thermal utilization. The result obtained showed:

- The optimum particle size and mixing ratios were 150 $\mu \mathrm{m}$ and 60:40, as it owned combustion properties and quality that fulfill the needs to be as firing source.

- The banana residue has a high potential to act as a natural binder for briquette production. It can prevent the susceptibility of briquette to crumble during the combustion process due to its lower lignin content and naturally sticky sap properties.

- The banana residue had significantly increase briquette density in by lowering the porosity and providing stronger bonding between the adjacent particles inside the briquette produced. 


\section{ACKNOWLEDGMENT}

The authors would like to acknowledge School of Bioprocess Engineering, Universiti Malaysia Perlis and thankful to Ministry of Higher Education, Malaysia under the Research Acculturation Grant Scheme (RAGS) 901800087 for the financial support extended to this research.

\section{REFERENCES}

[1] $10^{\text {th }}$ Malaysia Plan (2011-2015), 2011

[2] $\quad 5^{\text {th }}$ Fuel Diversification Policy, Malaysia, 2010.

[3] $11^{\text {th }}$ Malaysia Plan (2016-2020), 2016.

[4] J. Oladeji, "Theoretical aspects of biomass briquetting: A review study," Journal of Energy Technology and Policy, vol. 5, no. 3, pp. 72-82, 2015.

[5] D. B. Yahaya, and T. G. Ibrahim, "Development of rice husk briquette for use as fuel," Research Journal in Engineering and Applied Science, vol. 1, no. 2, pp. 130-133, 2012.

[6] A. A. Rahman, F. Sulaiman, and N. Abdullah, "The physical, chemical and combustion characteristics of EFB fuel briquettes," AIP Conference Proceedings, vol. 1657, no. 1, p. 040010, 2015.

[7] O. A. Sotannde, A. O. Oluyege and G. B. Abah, International Agrophysics 24, p. 189-194, 2010

[8] J. Kers, P. Kulu, A. Aruniit, V. Laurmaa, P. Krizan, L. Soos and U. Kask, "Determination of physical, mechanical and burning characteristics of polymeric waste material briquettes," Estonian Journal of Engineering, vol. 16, no. 4, pp. 307, 2010.

[9] K. Mohanta, D. Kumar, and O. Parkash, "Properties and industrial application of rice husk: A review," International Journal of Emerging Technology and Advanced Engineering, vol. 2, no. 10, pp. 86-90, 2012.

[10] A. Ma'ruf, B. Pramudono, and N. Aryanti, "Lignin isolation process from rice husk by alkaline hydrogen peroxide: Lignin and silica extracted," AIP Conference Proceedings, vol. 1823, no. 1, p. 020013 , 2017.

[11] D. Mohapatra, S. Mishra, and N. Sutar, "Banana and its by-product utilization: An overview," Journal of Scientific and Industrial Research, vol. 69, p. 323-329, 2010

[12] M. D. Hussin, and R. William, "Status of banana cultivation and disease in Malaysia," Crop Protection and Plant Quarantine Division, Department of Agricultural Malaysia, p. 60, 2010.

[13] M. Soffiner, "Pulp production from banana stem," University of Sao Paolo; 2011.

[14] N. Saari, R. Hashim, O. Sulaiman, and M. Sato, "The Influenced of Compression on Properties of Binderless Compressed Veneer Made from Oil Palm Trunk," International Journal on Advanced Science, Engineering and Information Technology, vol. 5, no. 5, pp.280-283. 2015 .
[15] I. I. Ikelle, O. Sule, and P. Ivoms, "Determination of the heating ability of coal and corn cob," IOSR Journal of Applied Chemistry, vol. 7 , no. 2 , pp. 77-82, 2014

[16] D. Huko, D. N. Kamau and W. O. Ogola, "Effects of varying particle size on mechanical and combustion characteristics of mango seed shell and cashew nut shell composite briquette," International Journal of Engineering Science Invention, vol. 4, no. 5, pp. 32-39, 2015.

[17] C. A. Raju, U. Praveena, M. Satya, K. R. Jyothi, and P. S. S. Rao, "Studies on Development of Fuel Briquettes using Biodegradable Waste Materials," Journal of Bioprocessing and Chemical Engineering, vol. 2, no. 1, 2014.

[18] A. C. Adetogun, K. M. Ogunjobi, and D. Are, "Combustion properties of briquettes produced from maize cob of different particle sizes," Journal of Research in Forestry, vol. 6, no. 1, 2014.

[19] D. K. Chirchir, and D. M. Nyaanga, "Effect of binder types and amount on physical and combustion characteristic," International Journal of Engineering Research and Science \& Technology, vol. 2, no. 1, 2013.

[20] N. Yalcin, and V. Sevinc, "Studies on silica obtained from rice husk," Journal of Ceramics International, vol 27, pp.219-224, 2001.

[21] D. Mohapatra, S. Mishra, and N. Sutar, "Banana and its by-product utilization: an overview," Journal of Scientific and Industrial Research, vol. 69, pp. 323-329, 2010.

[22] N. A. Musa, "Comparative fuel characterization of rice husk and groundnut shell briquettes," NJRED, vol. 6, no. 4, pp. 23-27, 2007.

[23] J. T. Oladeji, and M. Sc, "Fuel characterization of briquette produced from corncob and rice husk residue," Pacific Journal of Science and Technology, vol. 1, no. 1, pp. 101-106, 2010.

[24] J. Taiwo, and O. Ropo, "Investigation into physical and fue characteristics of briquettes produced from cassava and yam peels," Journal of Energies Technologies and Policy, vol. 3, no. 7, pp. 2007 2014, 2013.

[25] M. Yerizam, M. Marsi, and N. Novia, "Characteristics of composite rice straw and coconut shell as biomass energy resources (Briquette) (Case study: Muara Telang Village, Banyuasin of South Sumatra)," International Journal on Advanced Science, Engineering and Information Technology, vol. 3, no. 3, pp.232-238, 2013.

[26] C. C. Enweremadu, J. O. Ojediran, J. T. Oladeji, and I. O. Afolbi, "Evaluation of energy potential of huks from soybeans and cowpea," Science Focus, vol. 8, pp. 18-23, 2004.

[27] G. M. T. Arellano, Y. S. Kato, and F. T. Bacani, "Evaluation of fuel properties of charcoal briquettes derived from combinations of coconut shell, corn cob and sugarcane bagasse," in DSLU Research Congress 2015, 2015, paper 3, p. 1-6.

[28] J. O. Akowuah, F. Kemausuor, and S. J. Mitchual, "Physicochemical characteristics and market potential of sawdust charcoal briquette," in Proc. International Convention of Society of Wood Science and Technology, paper 3.1, p. 1, 2012.

[29] B. B. Nyakuma, A. Johari, A. Ahmad, and T. A. Tuan Abdullah, "Thermogravimetric analysis of the fuel properties of empty fruit bunch briquette," Journal Teknologi, vol. 67, no. 3, pp. 79-82, 2014. 